\title{
Frankenstein: quando a Ficção Científica questiona a Ciência
}

\author{
Frankenstein: when Science Fiction challenges Science
}

\author{
[Derônica Alves dos Santos Conceição' \\ Cristiane de Magalhães Porto ${ }^{1}$ \\ Edvaldo Souza Couto ${ }^{2}$ \\ 'Universidade Tiradentes (UNIT), Aracajú, SE, Brasil. Autora correspondente: veronica.alves@souunit.com.br \\ ${ }^{2}$ Universidade Federal da Bahia (UFBA), Salvador, BA, Brasil.
}

Resumo: Com suporte no romance Frankenstein, de Mary Shelley, o artigo defende a aproximação entre dois campos do saber, o literário e o científico, por meio da narrativa de ficção científica. O objetivo é discutir a relação ficção/Ciência onde a Literatura problematiza a Ciência a partir das relações socioculturais. O método usado foi o da pesquisa bibliográfica, de cunho revisão bibliográfica. Como resultado constatamos que a Ciência pode utilizar-se da Literatura para antever os possíveis desdobramentos sociais de decisões científicas e a ficção científica se singulariza por averbar o direito de indagar a Ciência e os avanços tecnológicos que marcam a existência humana. Concluímos que reconhecer a relação estreita entre ficção e Ciência induz a recolocá-la na condição de potencializadora de reflexão sobre o papel da intervenção científica no mundo.

Palavras-chave: Ciência e literatura; Ficção científica; Pesquisa bibliográfica.

\begin{abstract}
Based on the novel Frankenstein, by Mary Shelley, the article supports the approximation of two fields of knowledge, literature and science, through the narrative of science fiction. The objective is to explore the relation between science and fiction where literature challenges science from the viewpoint of sociocultural relationships. The method used was that of bibliographic research by means of a review. As a result, we have verified that science can make use of literature to anticipate possible social developments of scientific decisions and that science-fiction can be singled out because it records the right to investigate science and technological advances that show human existence. We concluded that recognizing the close relationship between fiction and science prompts us to place it in the condition of a promoter of reflection about the role of scientific interventions in the world.
\end{abstract}

Keywords: Science and literature; Science fiction; Bibliographic research.

Recebido em: 01/11/2019

Aprovado em: 17/08/2020 


\section{Introdução}

A ficção científica costuma ser apresentada ao público leitor como uma subdivisão da tipologia narrativa do romance por trazer na sua essência um predomínio à imaginação e uma diluição da realidade observada. Embora sua trama narrativa seja tecida a partir de conceitos científicos, a ficção é rejeitada por alguns cientistas por se tratar de uma narração marcada pelo caráter fantástico, e pela capacidade de envolver o leitor em um mundo inverossímil. Em meio a esse dilema, a ficção científica encontra-se em um não-lugar tanto no âmbito da Literatura, quanto ao da Ciência.

Alguns estudos com enfoque na educação em Ciência defendem a ficção científica como campo de diálogo entre a Ciência e a Literatura. Zanetic (1998, 2006), por exemplo, compreende que o ensino de Ciência, particularmente da Física, poderá ser potencializado pela adequação e leitura sistemática de obras literárias. O acervo literário contemplado pelo autor inclui não apenas os grandes escritores que, por possuírem uma veia científica, utilizam com propriedade conceitos e métodos científicos, mas, similarmente, obras escritas por cientistas que, guiados pela veia literária, produzem escritos científicos com sabor de Literatura.

Piassi (2007), outro exemplo, percebe três dimensões do conhecimento presentes nas narrativas de ficção: a conceitual-fenomenológica, a histórico-metodológica e a sóciopolítica. Para o autor, tais dimensões alocam o texto narrativo da ficção científica para um campo de fronteira entre a Literatura e a Ciência, e o escritor da narrativa como construtor do processo de autorizar-se para antever os desdobramentos de decisões científicas, a partir de determinada cultura em um contexto histórico.

Nesse contexto, diante do romance Frankenstein, o objetivo do artigo é discutir a relação ficção/Ciência onde a Literatura problematiza a Ciência a partir das relações socioculturais entre os avanços científicos e os sujeitos. O estudo explora possíveis sentidos que se revelam nas dimensões dialógicas que por ele ecoam. Logo, interessa entender em que medida a narrativa de ficção problematiza a Ciência a partir das relações socioculturais entre a Ciência e o homem. Foram elaboradas questões como: onde a Ciência e a Literatura se aproximam e se distanciam? Como a Ciência se apresenta na Literatura, ao tempo em que a Literatura exerce sua função reflexiva na Ciência? Essas indagações serão tratadas a partir da obra Frankenstein ou o Prometeu Moderno, de 1818, de Marry Shelley (1797-1851).

O método usado foi o da pesquisa bibliográfica, de cunho revisão bibliográfica, pois se propõe a apresentar, de modo breve, os conceitos de ficção científica e as aproximações entre a Ciência e a narrativa de ficção facilitadas pela capacidade inerente a Literatura de provocar reflexão e problematização, acerca das decisões tomadas pelo homem, particularmente nos campos social e cultural, a partir de um conjunto de autores e ideias selecionados para a investigação. Nesse sentido, é uma revisão de base teórica. Sua abrangência é temática, pois envolve um recorte transversal sobre a ficção científica a partir da obra Frankenstein (de 1818).

O artigo está organizado em três seções. A primeira trata da ficção científica como espaço de tessitura onde os fios da Literatura e da Ciência se entrelaçam para compor o tecido de uma narrativa envolvente, multifacetada e polêmica. A segunda seção aborda a história da escritora e o contexto de criação da obra Frankenstein. Considera-se o pensamento científico emergente no final do século XVIII e início do século XIX que eclode com a Segunda 
Revolução Científica. Na terceira seção, o enfoque está direcionado para os aspectos internos da obra. Aborda como o pensamento científico é reeditado pelo pensamento literário e as diversas possibilidades de desdobramentos que as decisões científicas poderiam acarretar na dimensão humana da vida.

O artigo conclui que a Literatura possibilita à Ciência antever as possíveis consequências de suas decisões no âmbito da cultura e do contexto histórico da vida humana. Singulariza a ficção científica em relação aos outros gêneros textuais pela capacidade de indagar a Ciência e os avanços tecnológicos que marcam a existência do homem. Portanto, perceber a relação estreita entre ficção e Ciência induz a recolocá-la na condição de potencializadora de reflexão sobre o papel da intervenção científica no mundo.

\section{Ficção Científica: Fios que Entrelaçam Literatura e Ciência}

O papel e as especificidades da narrativa de ficção científica resultam em significativa produtividade acadêmica no campo da Literatura. Para o romancista e crítico literário Roberts (2002, p. 1, tradução nossa), o gênero ficção científica é uma subdivisão da narrativa literária e se localiza no mundo ficcional, portanto, "[...] é uma ficção mais da imaginação do que da realidade observada, uma Literatura fantástica". Enquanto Literatura fantástica, a ficção científica assume como característica central provocar um estranhamento no leitor por causa de alguns elementos presentes na sua composição. O leitor, diante da narrativa, percebe a impossibilidade dos elementos fantásticos se concretizarem em seu mundo real, entretanto aceita a lógica da ficção como uma viagem para outra dimensão da existência, a imaginação.

Para Piassi (2007), a ficção científica traz um caráter realístico na sua narrativa. Essa semelhança ao real se efetiva a partir das três dimensões do conhecimento presentes na trama. A primeira é a dimensão conceitual-fenomenológica. Nesta dimensão, a narrativa apresenta os conceitos, os fenômenos e as leis da Ciência que estão vigentes durante um determinado contexto histórico. As descobertas científicas que estão em discussão, pelo seu caráter inovador ou pela ratificação de um conhecimento consolidado, costuma ser tematizado na Literatura de Ficção.

A segunda dimensão é nomeada histórico-metodológica. Nesse âmbito a Literatura questiona os valores éticos da prática científica. O foco está voltado para os efeitos, as consequências e os desdobramentos das descobertas e decisões científicas, considerando o contexto das relações histórico sociais, culturais e éticos do homem. As necessidades subjetivas e emocionais do sujeito encontram espaço fecundo na narrativa para se manifestarem, ao passo que sua trama convida o leitor a um estado de envolvimento emocional e empatia para com os sentimentos dos personagens envolvidos.

O aspecto sócio-político compõe a terceira dimensão do conhecimento presente na ficção científica. Trata-se das multirreferenciais entre a Ciência e a sociedade. Para Piassi (2007), o que caracteriza a ficção científica é o uso de mecanismos singulares de produção ficcional que, de um modo especial, arrazoa acerca do mundo natural e o questiona. A postura política se manifesta na medida em que, a relação texto/leitor se estreita e o sujeito se reconhece como participante de uma polis, em um estado de viver e conviver com o outro.

A partir dessas considerações, classificar a ficção científica apenas no campo da fantasia poderá incorrer em uma postura reducionista. Por outro lado, alocá-la como narrativa do real seria desconsiderar a riqueza do imaginário, da arte do narrar. Ferneda (2015) corrobora com esse pensamento, pois entende que a linha limítrofe entre o real e a fantasia é opaca. 
A ficção científica, por mais que tenha um caráter ficcional, conduz o leitor a questões de um mundo real. As concepções, as ideias, os valores, a visão de mundo, o conhecimento e a experiência do escritor transbordam para a narrativa e o leva a contextualizar o enredo a partir de um mundo concreto. Portanto, o mundo narrado na ficção está vinculado à realidade do mundo que o escritor experiencia e que deseja partilhar com o leitor.

Afinal, como a Ciência enxerga esse gênero literário? Onde a Ciência e a Literatura se aproximam e se distanciam? O que constitui um conhecimento como científico?

A concepção de Ciência que perdura, atualmente, foi construída a partir do século XIX, por conseguinte, se evidenciou em meado da Idade Moderna. Para Henry (1998), antes da Idade Moderna, o que existiu foi uma filosofia natural que pretendeu descrever e explicar o mundo em sua totalidade. A expressão 'Filosofia Natural' foi utilizada para explicar a compreensão dos fenômenos ocorridos no mundo físico. Essa Filosofia somada às técnicas de pesquisa desenvolvidas na época possibilitou a criação de novos conhecimentos e práticas que formaram blocos, próximos do que se conhece hoje como disciplinas científicas.

Com a passar dos anos, segundo Henry (1998), o termo Filosofia Natural foi transformado para se agregar a outras descobertas e se aproximou do que se conhece hoje como Ciência e seus termos correlatos, dentre eles a Revolução Científica e Ciência Moderna. De fato, a historiografia científica, nas suas várias vertentes, parece reconhecer uma presença da Filosofia na construção dos fundamentos da Ciência, na definição dos métodos científicos e na constituição dos seus objetivos. Porém, que lugar a filosofia ocupa na Ciência Moderna ainda é tema de controvérsia.

Para alguns historiadores, a Ciência e a Filosofia se separaram a partir da Modernidade porque a Filosofia não atende a uma exigência fundamental da Ciência Moderna: a produção de provas que tornem verdadeiros os conhecimentos produzidos. Desde a Modernidade, o conhecimento é científico quando produz provas e resultados, ao passo que o pensamento filosófico se empodera na capacidade de se refazer através da reflexão sem se preocupar com a comprovação do seu resultado.

Nessa direção, a Ciência não só se confronta com a Filosofia, ela encontra seu contraponto também com a Literatura. A Literatura é, em essência, um fenômeno estético. Se constitui um fazer artístico, cuja matéria prima é a palavra. O texto literário não objetiva informar, ensinar, doutrinar, pregar, documentar ou provarnada, embora, circunstancialmente, ele ensine, informe ou documente fatos a partir da contação de história, da análise filosófica, dos preceitos da Ciência e dos dogmas da Religião (COUTINHO, 2008).

Há a compreensão de alguns historiadores de que a Teologia, Filosofia e Ciência formariam uma unidade de pensamento. Para eles, não existe a constituição de uma Ciência sem Filosofia e sem uma série de ideias trans científicas que podem incluir a Arte e a Literatura (BARBOSA, 2013). Essa compreensão admite que, ao menos no âmbito da reflexão, os interesses da Literatura e da Ciência são convergentes. Para Coutinho (2008), a Literatura pode servir de veículo para emissão de diversos valores. O sentido literário reside no "[...] aspecto estético-literário que lhe é comunicado pelos elementos específicos, componentes de sua estrutura, e pela finalidade de despertar no leitor o tipo especial de prazer, que é o sentimento estético" (COUTINHO, 2008, p. 23), sem desconsiderar que o texto literário narra a partir do social, do histórico e do religioso.

Ainda sobre o conhecimento científico, Fourez (1995, p. 227) enxerga duas possibilidades de atitudes, uma delas é a idealista, caracterizada como uma postura de "[...] aceitação de normas universais e eternas que determinam de que modo é e deve ser o 
real". Nessa perspectiva, a Ciência é um conjunto de ideias eternas, válidas e inquestionáveis. Perde-se de vista que a realidade se transforma pela ação do homem, consequentemente, o conhecimento acerca dela, similarmente, se torna obsoleto e se renova. A segunda possibilidade de atitude, segundo Fourez (1995, p. 227) é denominada histórica. Nela, o sujeito enxerga nas "[...] configurações assumidas pela Ciência e pela ética o resultado de uma evolução, que não obedece necessariamente a leis eternas". A Ciência é fruto de criação intencional, cultural e historicamente situada. Trata-se de modelos explicativos, imperfeitos e temporários que assume recortes de certos aspectos da realidade e da relação homemhomem e homem-natureza.

Portanto, a concepção de Ciência que referencia esse estudo é que o acervo científico se constitui um conjunto de conhecimentos que permite compreender, descrever e explicar o funcionamento do mundo construído e reconstruído pelo homem, abarca o sentido da racionalidade científica, acrescido da reflexão filosófica.

O aparente distanciamento entre a Ciência e a Literatura nasceu de uma incompatibilidade criada pelos próprios atores das áreas. Conforme Snow (1995, p. 21), "[...] num polo, os literatos; no outro os cientistas, e, como os mais representativos, os físicos. Entre os dois, um abismo de incompatibilidade mútua - algumas vezes [...] hostilidade e aversão, mas principalmente falta de compreensão". Para autor, os cientistas das Ciências puras e aplicadas experienciam um fosso entre eles, apesar de estarem inseridos em uma cultura científica mais geral. Mas, os primeiros estão ainda mais separados das questões de cunho sociais.

A relação entre a Ciência física e a Literatura é tematizada por Zanetic (1998, p. 14) ao apontar um "[...] seleto grupo de cientistas [que] acabou produzindo obras ou longo trechos de obras, científicas ou não, que podem perfeitamente ser lidas também como obras literárias", são cientistas com veia literária. Dentre eles, consta Giordano Bruno, Johannes Kepler, Galileu, Isaac Newton, Charles Darwin, Ernest Mash, Albert Einstein e outros. Mais adiante no tempo, Zanetic (2006) defende que a discussão Física/Literatura, em especial a ficção científica e letras de música, alcança o campo da cultura. Advoga uma aproximação entre eles, na medida em que, os procedimentos científicos apresentam implicações éticas e sociais que se inserem no plano cultural. Levin (2014) entende que o desencontro da ficção científica com a Ciência é fruto de um mal-entendido generalizado que insiste em associar a ficção às Ciências Exatas e Naturais. Fato que não só limita o mundo amplo da Ciência como, também, nega à ficção a capacidade de incluir outras Ciências, a Epistemologia da Ciência e a Sociologia Científica. A ampliação do campo de visão permitiria enxergar a ficção em uma relação interdisciplinar entre Ciência, Tecnologia e Sociedade. Para o cientista, o elemento de estranhamento que compõe a trama narrativa da ficção se constitui uma forma de subversão sutil às regularidades das leis cognitivas que desenvolvidas para explicar a realidade, ou seja, a Ciência.

Ainda, na visão de Levin (2014), diferente de uma ficção que se avizinha da fantasia, a ficção científica de boa qualidade se ocupa de subverter aspectos concretos da realidade. Esses aspectos podem ser um detalhe de uma teoria historicamente fundamentada, uma alteração de uma constante física ou mesmo um conceito multidisciplinar. A ficção científica não só pode alterar regras biológicas, físicas, químicas e matemáticas como também pode alterar conhecimentos históricos, psicológicos ou sociais. Na visão de Eco (1989, p. 170), "[...] a boa ficção científica é cientificamente interessante não porque fala de prodígios tecnológicos [...], mas porque se apresenta como um jogo 
narrativo sobre a própria essência de toda a Ciência, isto é, sobre a sua conjecturabilidade". Assim, os elementos que caracterizam a ficção científica servem a um processo de especulação da realidade concreta de acordo com parâmetros racionais típicos da Ciência. Ainda, cabe à ficção a função de indagar o papel e o futuro do homem, a utilidade da tecnologia vinculada à responsabilização social e ambiental.

De fato, nenhum outro gênero textual averbou o direito de indagar com tanta sagacidade a Ciência e os avanços tecnológicos que marcam a nossa passagem pelo mundo. Reconhecer a relação estreita entre Ficção e Ciência nos leva a recolocá-la na condição de potencializadora de reflexão sobre o papel da intervenção científica no mundo.

\section{A Obra Frankenstein e seu Contexto de Criação}

Quem escreveu Frankenstein? Mary Wollstonecraft Godwin Shelley (1797-1851), ou simplesmente, Mary Shelley. Se a resposta parece óbvia aos olhos do leitor contemporâneo, não era tão evidente no início do século XIX. De fato, quando a primeira edição da obra foi publicada, em 1818, seus 500 exemplares não apresentavam o nome do autor ${ }^{1}$. Ter o prefácio assinado pelo marido, Percy Bysshe Shelley (1792-1822), contribuiu para levantar pistas duvidosas acerca da verdadeira autoria de Frankenstein. Entretanto, a decisão pelo anonimato pareceu ser a mola impulsora da publicação, depois da recusa do manuscrito pelos editores John Murray e Charles Ollier, em 1817 (GUIMARÃES, A. R., 2018). À vista dos editores e do público leitor, pareceu inusitado que uma jovem inglesa de 18 anos fosse capaz de criar um enredo que sinalizou nuances de um novo modelo literário.

Nesse ponto de discussão parece evidente a necessidade de abordar pelo menos três questões que se levantaram como barreiras à publicação do manuscrito de Frankenstein autografado por Mary Shelley: o contexto sociopolítico da Inglaterra no final do século XVIII e início do século XIX; o gênero literário em circulação no período; e a condição de ser mulher e jovem num mercado, marcadamente, assumido por homens.

O século XVIII trouxe transformações sociais, políticas e econômicas que desestabilizaram a Inglaterra. Os anos setecentos favoreceram algumas reviravoltas sociopolíticas que eclodiram em forma de revoluções econômicas, dentre elas a Revolução Industrial (1760-1860), e de revoluções no campo da Ciência, na forma de Revolução Científica (entre os anos 1550-1770, aproximadamente). No primeiro caso, o aparecimento de indústrias de tecidos de algodão, da máquina a vapor e do tear mecânico reconfigurou o modo de produção e de viver dos britânicos. No segundo, a Ciência, que até então estava atrelada à Teologia e à Filosofia, passou a ser entendida como um conjunto de conhecimentos estruturado e prático, adquirido por meio de técnicas de pesquisa, fatores esses que, modificaram o modo de pensar dos ingleses.

O novo contexto de produção material, organização social e formalização do pensamento na Europa despertou uma forma sutil de ansiedade, medo, terror e horror do futuro no imaginário do europeu, aqui particularmente tratado, o inglês citadino (GUIMARÃES, A. R., 2018). Esse composto de transformações sociais, econômicas e subjetivas que perfila o mundo britânico setecentista se reflete na Literatura e se corporifica no Romance Gótico.

\footnotetext{
${ }^{1}$ A primeira edição de Frankenstein foi publicada em 1 de janeiro de 1818 em Londres, pela casa editora Lackington, Hughes, Harding, Mavor \& Jones. A obra foi dividida em três volumes, com um prefácio assinado por Percy Shelley e dedicado a William Godwin, mas sem indicação do nome do autor(a) da obra.
} 
A Literatura Gótica se constitui uma vertente do Romantismo, cujo foco voltou-se para o mistério, a fantasia e o fantástico. Em desvio das vivências ou devaneios românticos das personagens, os temas costumam ser voltados à morte, aos sonhos, ao satanismo e à insanidade humana. Como artifício para despertar o medo, os enredos costumam desenvolver-se em castelos e abadias em ruínas, calabouços úmidos, vilões terríveis, monges loucos, heroínas em perigo, câmaras secretas, galerias assombradas, portas chiando, retratos misteriosos e fantasmas (GUIMARÃES; ARAÚJO, 2018).

Segundo P. A. Guimarães (2018), na época em que Mary Shelley começou seus escritos já havia algumas mulheres escritoras de romances do gênero gótico, mas a criação literária da jovem inglesa, apesar de ser classificada na categoria, anunciou uma transgressão nesse modelo de narrativa. Mary Shelley conseguiu mesclar no enredo de Frankenstein a verossimilhança, próprio da Literatura, e a modernidade, característica do seu contexto de produção. Para a autora, a obra prefigura "[...] um conto fantástico com origem num interesse condizente com a sua época progressivamente positivista e empirista: a especulação (pseudo-) científica." (GUIMARÃES, P. A., 2018, p. 176).

De fato, o fio condutor da narrativa de Frankenstein é a Física, sustentada pela Ciência Moderna, ao invés da Metafísica, como na Literatura Gótica. Mary Shelley considera o pensamento científico emergente no final do século XVIII e início do século XIX, quando uma das preocupações dos cientistas era desvendar o funcionamento da Natureza, a origem da vida na terra e o exercício da consciência humana.

Conforme P. A. Guimarães (2018), a magia que permeava a Ciência Moderna era o conhecimento sobre a natureza que, com os artefatos certos, poderia ser exposto e controlado pelo homem. Sessões públicas ou palestras eram organizadas por professores de Filosofia Natural para apresentar ao público leigo o que ele entendia serem experiências científicas. Mary Shelley estivera algumas vezes nesses encontros e absorveu o que existia de Ciência na sua época, fato que contribuiu para a surpreendente inovação em seu romance com tema instigante e transgressivo em relação à Literatura Gótica.

A produção de Mary Shelley aborda a temática científica com suporte na medicina, na anatomia e nos conhecimentos físico e químico com o uso da prática de galvanização. Somada às noções de Ciência, a autora trouxe para a narrativa uma carga de drama com dimensões moral e filosófica. Na época, sua produção foi classificada como Literatura de Terror, pois não havia a percepção contemporânea de ficção científica. Mas, não se pode negar que ela dera um passo à frente por criar uma história de terror a partir das aspirações científicas, ao invés de narrar apenas sobre monstros naturais ou sobrenaturais.

Frankenstein é uma das obras pioneiras que apresenta a semente de um novo gênero textual, a ficção científica, que extrapola o estilo sobrenatural característico do romance gótico para se referenciar no conhecimento natural da invenção científica, originário da Ciência e da Técnica sem abrir mão do terror e do fantástico. Nesse sentido, Guimarães e Araújo (2018, p. 73) entendem que o Prometeu Moderno não é uma obra fácil de classificar, pois escapa aos padrões literários estabelecidos, ao tempo que assume um molde singular de escrita e se multiplica nas possibilidades de "[...] leituras e interpretações desde a crítica literária, à leitura política, filosófica, sociológica, educativa, psicanalítica, marxista, feminista, científica, mitológica, ecológica e até vegetariana".

De acordo com A. R. Guimarães (2018), existem inúmeras possibilidades de enxergar a autora de Frankenstein a partir dos relatos históricos-literários e a partir dos esboços biográficos rastreados nos diários publicados. Histórica e literariamente, a imagem de 
Mary Shelley esteve atrelada ora a um gênero literário pouco relevante (seja o estilo gótico desgastado ou as noções primárias de ficção científica), ora a imagem de uma jovem mulher prisioneira de seu marido ou da própria criatura monstruosa. Segundo o autor, mesmo quando revelado que a obra "[...] era fruto literário de uma mulher, os críticos passaram a dizer que aquilo se devia à influência e ajuda de Percy B. Shelley mais do que ao génio criativo de Mary Shelley". (GUIMARÃES, A. R., 2018, p. 34).

No prefácio da obra, a autora revela uma inquietação comum aos seus leitores, voltada à capacidade de produção de uma jovem. "Será um prazer para mim, pois darei uma resposta genérica à pergunta que tantas vezes me é dirigida: 'Como eu, na época uma menina, vim a conceber e a desenvolver uma ideia tão aterradora?'" (SHELLEY, 1994, p. 11). Ao oferecer uma resposta genérica ao público leitor, a autora alude aos traços da sua personalidade tímida, a influência dos pais e do marido, bem como seu ambiente de formação como justificativas para sua genialidade criativa precoce. Foi sincera e realista ao tempo que afirmou uma posição opaca diante de outros nomes tão importantes quanto o seu.

Mary Shelley revelara nos seus esboços biográficos uma identidade construída e reconstruída junto à história de sua família. Na visão de A. R. Guimarães (2018, p. 33), trata-se de uma mulher "[...] inteligente, extremamente culta, trabalhadora intelectual incansável, que teve uma vida difícil, ferida por várias tragédias pessoais, uma vida amorosa e um casamento complicado." Contudo, uma mulher com "[...] uma vulcânica ambição para ser reconhecida pelos seus próprios méritos, mas em surdina, como convinha a uma mulher do seu tempo".

Um ponto de vista para compreender Mary Shelley é vê-la como uma jovem mulher em busca do conhecimento sobre si, em luta para se libertar dos monstros que se apropriaram de sua história e identidade: o pai, a mãe, o marido, os escândalos que marcaram sua vida e as tragédias que criaram fissuras em seu coração. Assim, as pessoas que orbitaram a sua existência e os acontecimentos que marcaram a sua história tornaram-se a linha que costurou sua carne, que traçou o seu modo de viver consigo e com o outro, e que teceu a sua (falta de?) perspectiva de futuro. Juntos, contribuíram para a criação de um monstro com muitas faces (ou seria: muitas faces que compõem um monstro?) que, problematiza as necessidades psicoemocionais e sociais do homem na medida em que ilumina as possibilidades das promessas oferecidas pela Ciência Moderna.

\section{A Ciência em Frankenstein. Frankenstein na Ciência?}

Analisar a relação entre a Ciência e a Literatura de ficção científica é como lidar com um jogo de espelhos onde a Literatura reflete as múltiplas imagens da Ciência ao passo que os preceitos científicos contornam o perfil da Criação Literária. De fato, a arte literária pode se apresentar como um documento que revela o imaginário e as representações de um determinado contexto social em um período da História. A narrativa permite desvendar os anseios e a visão de mundo dos atores sociais acerca das transformações que marcaram seu tempo. A Ciência, quando desvinculada das dimensões humana e social que desenham o imaginário coletivo, pode sucumbir a posturas científicas autoritárias e restritas aos espaços laboratoriais.

No caso da obra de Mary Shelley, a multiplicidade de vozes narrativas, durante relatos de um mesmo acontecimento, permite entender as profundas e divergentes concepções acerca dos avanços científicos pelos quais passava a Europa na transição do século XVIII para o século XIX. A primeira fase da Revolução Científica abalou o 
pensamento científico e filosófico do século XVII com as descobertas de Newton e as dúvidas metódicas de Descartes. Mais tarde, no início do século XIX, a Europa, principalmente a Inglaterra, conviveu com um novo modelo de conhecimento científico emoldurado em um contexto pós Revolução Industrial e pós Revolução Francesa.

Ademais, surge nessa conjuntura europeia um movimento artístico-literário que eclode como resistência aos períodos das Luzes, o Romantismo. Assim, a Ciência Moderna disputa espaço de convivência com os conhecimentos da Química, da Biologia e da Filosofia Natural ao som de notas do Romantismo. Como esse composto se reflete na obra de Mary Shelley?

O Frankenstein que compõe o título do romance é Victor Frankenstein e não a criatura. Segundo Araújo (2014), considerar a Ciência a partir do criador, não apenas faz sentido como respeita o título do próprio romance. No entanto, parece irrefutável que durante o desenvolvimento e no desfecho da narrativa os dois, Victor e sua criatura, se confundem ao ponto de compartilharem os mesmos sentimentos conflitantes e objetivo de vida: matar o outro. Estes seres conduzem o leitor a refletir como o "[...] homem é imagem porque se transcende [...] no não pode dizer, mas aspira irresistivelmente à recuperação da linguagem como uma realidade total" (PAZ, 2006, p. 38, 45). É como uma etapa natural entre os dois, daquilo que se considera como destino humano, que só a recuperação da linguagem pode mostrar como ela e o homem seguem juntos. O que é diferente no homem é que ele é uma ponte e não um subterfúgio: o que o faz humano. Ou seja, o humano é considerado como homem por meio do seu projeto de criação de si.

As várias possibilidades de leitura que a obra apresenta, a partir dos diversos personagens que envolve, apresenta a necessidade de delimitar o enfoque: a Ciência em Frankenstein (criador e criatura) que corporificam a obra. Afinal, o romance se caracteriza por conseguir "[...] equilibrar perspectivas contraditórias da natureza humana dentro de uma história. Frankenstein, o personagem central, é tanto herói quanto pecador; a sua criação é tanto feito grandioso quanto um crime hediondo" (HITCHCOCK, 2010, p. 18), o reflexo das representações da Ciência na época.

Finalmente, como a Ciência se apresenta em Frankenstein? Como os avanços científicos do século XVIII povoam o imaginário coletivo reproduzidos por meio da escrita pela autora do romance? De modo direto, o fazer científico se apresenta em ações de caráter aplicado e experimental ao gosto da visão mecanicista, predominante entre os intelectuais da época. A Ciência aplicada migra do campo da Filosofia da natureza para o campo da Engenharia preocupada com a Revolução Industrial em curso (FIGUEIREDO, 2009).

O objetivo do conhecimento científico passou a oferecer técnicas e instrumentos capazes de transformar a realidade e não, apenas, compreendê-la. Conforme Santos (1988, p. 6), o "[...] determinismo mecanicista é o horizonte certo de uma forma de conhecimento que se pretende utilitário e funcional, reconhecido menos pela capacidade de compreender profundamente o real do que pela capacidade de o dominar e transformar". O homem passou a entender que tudo é possível quando se tem conhecimento das leis que regem os fenômenos e as controlam pelo uso da razão. Daí surgiu a concepção de que a sociedade pode ser reformulada a partir dos princípios racionais, bandeira defendida durante a Revolução Francesa (1789-1799).

O novo modelo de Ciência transformou a mentalidade da geração de pensadores britânicos durante os séculos XVIII e XIX. Conforme Goldfarb (2001, p. 160-161) surgem a partir daí, nomes como os de "Boyle, Newton e Hooke, para citar apenas alguns mais 
importantes. Estes se tornariam viáveis por meio de seus trabalhos, a interpretação já feita pelos continentais do universo como um grande relógio mecânico de fácil manipulação". Esse relógio mecânico é formado por peças, dentre elas o homem. Assim, o campo da medicina sofre grande impulso e a origem da vida começou a ser escrutinada via experimentos.

No contexto de vida de Mary Shelley, duas forças de polos opostos se atraem. De um lado os pensamentos mecânico e racionalista sustentavam a Ciência Moderna, de outro lado o pensamento romântico e de valorização do homem enquanto sujeito de sentimentos e subjetividades se edificava. O Romantismo inicia na Alemanha por volta de 1800, se expande para a Inglaterra e França e se espalha por toda a Europa e América. Para Guinsburg (1993), o Romantismo é um movimento que inaugura a modernidade e rompe com os ideários vigentes não só no campo da Literatura, mas no campo científico e filosófico. Por isso o Romantismo se opõe a uma determinada visão de mundo que se estabeleceu pós Revoluções Industrial e Francesa.

O racionalismo, na acepção dos românticos, contribuiu para afastar o homem da natureza e da subjetividade inerente ao ser, tira-lhe a liberdade de sentir e viver. Para Figueiredo (2009), ao descrever a visão de mundo e de homem que enfronha o movimento, houve uma retomada dos conceitos pré-românticos onde a vida requer o sentimento como um fator preponderante para sua autenticidade. Logo, uma evidente amálgama das correntes filosóficas, científicas e literárias está presente na personagem Victor Frankenstein.

Por outro lado, Victor Frankenstein logo revela perceber as mudanças no modelo de Ciência, o sentimento de desprezo pelos alquimistas e a demasiada valorização do pensamento emergente. Ao mencionar os nomes dos alquimistas estudados, o professor não reluta em afirmar "[...] cada minuto, cada instante que dedicou a tais livros, foi totalmente desperdiçado. Sobrecarregou a memória com sistemas e uma nomenclatura inúteis." (SHELLEY, 1994, p. 45). Assim, o tempo dedicado ao estudo das Ciências naturais, organicista e herméticas de influências aristotélicas e platônicas, respectivamente, parece se comprovar no relato de uma tempestade que precedeu a sua descoberta da eletricidade, do choque elétrico e do relâmpago:

\footnotetext{
Antes disso eu não estava ainda familiarizado com as mais elementares leis da eletricidade. Aconteceu que encontra-se em nossa companhia um homem de grande saber no campo da Ciência natural, que, a propósito da catástrofe, começou a explicar uma teoria que criara, sobre o tema da eletricidade e do galvanismo, fenômenos novos e surpreendentes para mim. (SHELLEY, 1994, p. 41).
}

No campo da Ciência, as descobertas acerca da eletricidade passaram a se evidenciar durante a Segunda Revolução Científica. Experimentos eram feitos com vistas a comprovar a relação da corrente elétrica com a origem da vida. O galvanismo, experimento no campo da biologia em que a eletricidade direcionada a um corpo físico é capaz de contrair os músculos, foi descoberto por Luigi Galvani (1737-1798). A partir daí, conclui-se que o elemento vital que animava a vida estava relacionado diretamente com a eletricidade.

Assim, Frankenstein, conhecedor dos experimentos galvânicos e da eletricidade, abraça a nova forma de fazer Ciência como superior à perspectiva alquímica de Magno, Agrippa ou Paracelso (1493 a 1541). Utilizou seus conhecimentos da física e da química modernas, suas noções de anatomia e medicina e seus experimentos elétricos para dar vasão a um desejo pessoal: criar uma vida. 
Foi numa noite lúgubre de novembro que contemplei a realização de minha obra. Com uma ansiedade que quase chegava à agonia, recolhi os instrumentos a meu redor e preparei-me para o ponto culminante do meu experimento, que seria infundir uma centelha de vida àquela coisa inanimada que jazia diante dos meus olhos. $\mathrm{A}$ chuva tamborilava nas vidraças. Então, deu-se o prodígio. (SHELLEY, 1994, p. 55).

Embora não se registre o termo eletricidade, ele fica implícito na oração "[eu] infundi uma centelha de vida àquela coisa inanimada que jazia diante dos meus olhos". A própria Mary Shelley admite a fonte que inspirou a narrativa onde Victor realizou o "prodígio", o Dr. Darwin "[...] que havia guardado um pedacinho de vidro até que, por algum meio extraordinário, ele começou a se mover voluntariamente" (SHELLEY, 1994, p. 11).

Erasmus Darwin (1731-1802), avó de Charles Darwin (1809-1882), era poeta e cientista, amigo do pai de Mary Shelley, William Godwin, e com quem a escritora, possivelmente, teve contato. Esse cientista defendia a teoria da transmutação da espécie no fim do século XVIII, onde espécies de vida simples poderiam ser formadas a partir de restos de seres vivos mais complexos (GOMES, 2018).

Frankenstein materializa o conhecimento mecânico-experimentalista da Ciência oitocentista, aplica os avanços científicos no campo da Medicina e Biologia e revitaliza o objetivo maior da alquimia. Passa a frequentar os cemitérios com o objetivo de "[...] analisar cada fase de transição da vida para a morte e da morte para a vida [...] via de perto como a forma humana se degradava e se corrompia [...] via essa coisa maravilhosa que é um olho, ou um cérebro, tornar-se a fonte de nutrição de um verme" (SHELLEY, 1994, p. 50).

Assim, o método científico racionalista, experimentalista, aplicado no campo da biologia, foi provado verdadeiro por meio dos intentos de Frankenstein, que "[...] após dias e noites de incrível esforço e cansaço, logrei descobrir a causa fundamental da geração e da vida. E mais do que isso, tornei-me capaz de animar a matéria sem vida" (SHELLEY, 1994, p. 51).

A conclusão elaborada por Victor acerca da sua capacidade como criador revela que, possivelmente, a escritora chamou para o âmbito da discussão outra concepção de Ciência que habita sua época, a do químico Humphry Davy (1778-1829) ${ }^{2}$. Ele descobriu a existência de dois tipos de eletricidade, a positiva e negativa, e que corpos com polos diferentes se unem. Essa descoberta, além de criar uma nova terminologia para a química e contribuir para a tabela periódica, reforma "[...] a ideia de que o cientista deve assumir uma posição ativa com relação a natureza" (GOMES, 2018, p. 857).

Como cientista, Victor Frankenstein passou a se voltar exclusivamente para os experimentos naturais. Suas relações familiares e sociais foram secundarizadas:

Sem qualquer pausa para descanso, regressei imediatamente a Genebra. [...]. Meu aspecto cansado e em desalinho alarmou a todos, mas deixei sem resposta as perguntas ansiosas com que me assaltaram. Não me sentia com o direito de reivindicar a solidariedade dos meus, e mesmo sua companhia me parecia uma dádiva imerecida. Contudo, amava-os ao extremo e, para os salvar, resolvi dedicarme à minha abominável tarefa. A perspectiva de tal ocupação relevava a um plano secundário todos os aspectos da vida ao meu redor e toda a realidade se concentrava naquele pensamento. (SHELLEY, 1994, p. 139).

${ }^{2}$ Em 1820 Davy foi nomeado presidente da Royal Society of London, o que constituiu brilhante coroamento à sua carreira científica. 
Assim, a Ciência do século XVIII e XIX foi tematizada no romance de Mary Shelley desde as mudanças nos modelos científicos, os experimentos e as especulações que marcaram a aplicabilidade irrestrita da Ciência na modernidade, até o perfil do trabalho solitário do cientista.

Por fim, uma outra questão diz respeito a uma possível presença de Frankenstein na Ciência. Esse ponto será tratado a partir de noções da ética, da moral e dos ideais do Romantismo materializados na criatura, o reflexo de Victor Frankenstein.

Inicialmente, vale ressaltar que, o termo ética deriva do grego ethos, com possibilidade de duas grafias, êthos que se referia, inicialmente, o lugar onde se guardavam os animais, tendo evoluído para o lugar onde brotam os atos, isto é, a interioridade dos homens; e éthos que se relaciona ao comportamento, aos costumes, o hábito, o caráter, modo de ser de uma pessoa. Enquanto a palavra moral, que deriva do latim mos-, (plural-mores), se refere a um conjunto de costumes, normas e leis de uma determinada sociedade e cultura. De acordo com Pedro (2014, p. 485), "[...] a ética tem por objeto de análise e de investigação a natureza dos princípios que subjazem a essas normas, questionando-se acerca do seu sentido."

Assim, a moral enfoca o como a vida se processa em determinada sociedade e cultura emoldurada pelas normas e costumes, ao passo que a ética questiona o porquê viver segundo $x$ ou y modo. A partir do questionamento ético, Mary Shelley parece construir sua concepção de Ciência sob um olhar crítico, desvela a problemática de um método científico mecanicista despreocupado com os aspectos subjetivos do homem. A Ciência que busca uma utilidade e se presta como alavanca do desenvolvimento industrial poderá incorrer em problemas "monstruosos" e desumanos.

Nesse aspecto, Mary Shelley permite que a influência familiar aproxime a Ciência da arte literária, induzindo a sociedade inglesa a pensar uma Ciência com um método mais humano, a partir de novas perspectivas e novos padrões de moral. Nada inesperado para a filha de um filósofo, anarquista e romancista inglês, William Godwin; da escritora Mary Wolstonecraft, romancista e feminista inglesa; e amante-esposa de Percy Bysshe Shelley, um dos poetas mais famosos de Inglaterra, artífice de uma poesia social e humanamente comprometida, num tom claramente profético, inconformista e irreverente (GUIMARÃES, A. R., 2018).

Ao expressar o conflito entre as crenças sociais de natureza metafísica e as possibilidades criativas da Ciência, a escritora revela, no prefácio da obra, que "[...] talvez se pudesse reanimar um cadáver; as correntes galvânicas tinham dado sinal disso; talvez se pudesse fabricar as partes componentes de uma criatura, juntá-las e animá-las com o calor da vida." (SHELLEY, 1994, p. 11).

É fato que, devendo ou não ser criada pelo homem, Victor Frankenstein deu cabo de sua tarefa, atuando como um Prometeu Moderno, enfrentando os limites divinamente instituídos para satisfazer uma ambição pessoal. Admite que "[...] chafurdava na umidade dos sepulcros, ou esquartejava o animal vivo para aproveitar-lhe o sopro de vida na recomposição da minha criatura [...], não poucas vezes minha própria natureza repugnava esse tipo de atividade" (SHELLEY, 1994, p. 55).

Nesse trecho da obra a autora lança mão das noções de ética e da moral para criticar às diversas concepções sobre o homem e a vida que sustentavam a Ciência mecanicista. Primeiro, o homem enquanto máquina poderia ser construído por unir suas partes e compor sua estrutura física a partir de espécies de vida mais simples e de seus pares. Por outro lado, a montagem de peças para formar um corpo de homem poderia causar estranhamento por 
parte dos outros membros da espécie e levar a sua exclusão do coletivo, uma vez que a estética e a aparência comum à espécie se torna o primeiro convite a socialização. Vítima do descaso desse aspecto do social, a criatura passou por várias situações de repulsa, inclusive pelo próprio criador.

Ninguém poderia suportar o horror do seu semblante. Uma múmia saída do sarcófago não causaria tão horripilante impressão. Quando o contemplara, antes de inocular-Ihe o sopro vital, já era feio. Mas agora, com os nervos e músculos capazes de movimento, converteu-se em algo que nem mesmo no inferno dantesco se poderia conceber. (SHELLEY, 1994, p. 56).

Segundo, a criação do homem a partir de partes de outros animais coloca o homem no mesmo plano de privilégio. Ao se tirar Deus do processo criativo, a racionalidade dita que as únicas criaturas que privilegiam o humano são os próprios humanos. Não há doutrina ou autoridade universais que legitimem esse senso de superioridade. Mas a vida na polis, regida pela cultura dita que os homens se completam, em atos de formar o outro, forma a si mesmo como humanos.

Parece esquecer, Frankenstein, que me deve a mesma igualdade de tratamento que dispensa a seus semelhantes, e que tenho direito à sua clemência e mesmo ao seu afeto. Lembre-se de que é meu criador. Quanto a mim, em vez de um novo Adão, sou o anjo decaído que você priva do direito à alegria, sem que me caiba culpa. De todas as benesses de que tenho conhecimento, eu sou sempre irrevogavelmente excluído. No entanto, eu era bom e compreensivo. Foi a desgraça que me converteu em demônio. Devolva-me a felicidade e voltarei a ser virtuoso. (SHELLEY, 1994, p. 94).

Terceiro, o ato criativo possibilitado pela Ciência Racionalista e Experimentalista não é tão racional quanto se pretende, uma vez que é permeado pelas emoções, impulsos e desejos do criador. De fato, a pretensa racionalidade foi foco de ferrenhas críticas por parte do Romantismo. Por sua vez, a criatura passa a revelar qualidade essencialmente humanas. Suas necessidades são, demasiadamente, compreendidas por serem comuns aos homens: uma família, contatos físicos permeados de afetos, dentre outros. Frankenstein descreve o emaranhado de emoções que o assolam diante de uma cena de afetividade.

Ele tocou uma ária suave e dolente, que, pude perceber, provocou lágrimas nos olhos de sua prestimosa companheira sem que o homem notasse, a não ser quando emitiu um breve soluço. Ele passou a produzir sons diferentes, e a bela moça, largando o trabalho, ajoelhou-se a seus pés. Ele a fez levantar-se e sorriu com tal doçura, que senti um misto de dor e prazer que jamais experimentara antes. Saí do meu posto de observação para fugir a esse novo torvelinho de emoções (SHELLEY, 1994, p. 101).

A própria ausência de um nome pessoal para a criatura desperta a sensibilidade do leitor, que reconhece o nome como símbolo de uma identidade do homem e que define a linha genealógica da sua existência. Não é à toa que a criatura, feito a semelhança humana, fica abalada diante da pergunta de De Lacey sobre qual seria o seu nome. Conforme narra "[...] pensei, era o momento decisivo que me daria ou me tiraria a felicidade para sempre. Esforcei-me por adquirir a firmeza necessária para responder-lhe, mas esse esforço consumiu toda a energia que me restava. Caí da cadeira e fiquei a soluçar". (SHELLEY,1994, p. 126).

A relação meio versus natureza também é convidada a participar da narrativa. Afinal, como a Ciência Mecânica explica a formação da persona? O que constitui o homem, a ordem biológica, inata, natural, hereditária, ou o resultado da interação com o meio? Ao abordar 
a temática, Mary Shelley traz as marcas das teorias filosóficas de John Locke (1632-1704) e Jean-Jacques Rousseau (1712-1778), para os quais o meio interfere diretamente na formação do sujeito, seja para edificá-lo ou corrompê-lo.

Vim a saber que essa gente tinha um meio de comunicação recíproca de seus atos e
sentimentos por meio de sons articulados. Percebi que esses sons causavam prazer
ou dor, sorrisos ou tristeza, no espírito e semblante dos que se comunicavam. Era
sem dúvida uma Ciência dos deuses, e ardentemente desejei familiarizar-me com ele.
(SHELLEY, 1994, p. 105).
Creia-me, Frankenstein, eu era bondoso. Trazia amor e humanidade dentro da alma,
antes que viesse a ficar só, miseravelmente só, como agora. Se você, que é meu
criador, me renega, que posso esperar de seus semelhantes, que nada me devem?
Deles só tenho recebido o escárnio e a repulsa. (SHELLEY, 1994, p. 94).

Mesmo diante de um assassino de inocentes, Frankenstein desperta nos seus semelhantes a compaixão e a compreensão pelos seus atos justificados pela necessidade de ser aceito e amado. Diz a narrativa "Todo homem - bradou ele - tem direito a uma esposa, toda bestafera encontrará sua companheira, e somente a mim isso será negado? Meus sentimentos afetivos foram pagos com ódio e opróbrio. Você, homem! Pode alimentar o ódio". E produz a sentença, "Suas horas hão de passar-se em terror e infortúnio, e não tardará em despenhar-se o raio que destruirá para sempre sua felicidade. Julga-se com direito a ser feliz enquanto eu vivo em maldição?" (SHELLEY, 1994, p. 157).

Assim, o romance de Mary Shelley traz para a trama narrativa os avanços da Ciência Moderna ao tempo em que questiona os valores éticos das descobertas e dos experimentos científicos. O saber científico voltado para o controle absoluto sobre as forças da natureza com vista ao progresso da indústria não pode se estabelecer em detrimento aos valores humanos nos seus aspectos emocionais e subjetivos.

Frankenstein traz à baila reflexões direcionadas aos objetivos dos avanços da Ciência na modernidade por apresentar possíveis desdobramentos éticos para as decisões tomadas no campo científico. Apresenta a condição humana em sua completude. O homem é mais do que uma máquina onde cada peça contribui para o funcionamento do seu corpo. O humano é social, cultural e possuidor de sentimentos subjetivos que definem e ressignifica seu estado no mundo.

Na outra via, levanta a possibilidade de existir um Frankenstein no campo científico na medida em que as concepções de Ciência não podem desconsiderar as possibilidades que habitam o desconhecido ao homem. O conhecimento só será verdadeiramente racional quando reconhecer que o que se conhece é um campo restrito e limitado em comparação com o conhecimento que está ainda por ser desvendado. O desconhecido assusta, cobra a atenção e reverência da Ciência. Igual a um monstro a se revelar, as possibilidades delimitam as ações e as tomadas de decisões, sob pena de gerar um desgaste ainda maior para apagar os rastros deixados. A saga de Victor Frankenstein para desfazer o seu ato criativo foi muito mais dolorosa do que o fascínio em criar uma vida. Nisto a Ciência tem muito o que aprender.

\section{Espaço das Inserções e Conclusões}

O fascínio que a obra de Mary Shelley exerce sobre os seus leitores reside, possivelmente, nas múltiplas possibilidades de leituras, sem que uma desfaça a outra 
ou uma delas se sobreponha como superior às demais. Nesse contexto, esse estudo permite algumas conclusões das quais destacamos quatro.

A primeira conclusão é que foi possível identificar na personagem principal, Victor Frankenstein, as marcas da Ciência Moderna de base mecanicista e experimentalista, a influência da Filosofia Natural nas vertentes organicista e hermética, os pensamentos iluministas de Locke e Rousseau e os anseios pelas especulações científicas de Darwin e Galvani. Ao tempo em que a ética, os valores, a subjetividade, os desejos, os sentimentos e a influência do movimento Romancista presente na Inglaterra se materializam na criatura.

A segunda conclusão é que a relação de Victor Frankenstein com a sua criação é profundamente problematizada pela autora durante toda a narrativa. Movido pelo desejo de controlar as leis da natureza, de alcançar a glória diante dos seus semelhantes e do ser criado, o cientista Frankenstein se averba o direito de atribuir vida humana a um corpo confeccionado por ele a partir de outros seres. Porém, esse ato criativo possibilitado pela Ciência dá vida a uma criatura que problematiza os avanços científicos em detrimento dos aspectos subjetivos, sociais e emocionais inerentes ao homem.

A terceira conclusão é que a partir da relação entre o criador e a criatura, Mary Shelley leva o leitor a pensar no compromisso que a Ciência deve exercer com as consequências de suas decisões, nos possíveis desdobramentos do fazer científico que modela e limita a liberdade de ação de cada sujeito. Afinal, o que poderia ser um final glorioso se transformou na existência de dois personagens que partilham as mesmas emoções, sensações e sentem-se infelizes e rejeitados. Ironicamente, os sentimentos são causados um pelo outro. Frankenstein devido aos atos vingativos da criatura, e a criatura devido a negação à felicidade por parte de seu criador.

A quarta conclusão é que a ficção científica se utiliza de seu espaço inverossímil para antever os possíveis desdobramentos sociais de decisões científicas, na perspectiva da cultura e do contexto histórico. Bem como, anuncia uma relação estreita entre ficção e Ciência que induz o leitor a recolocá-la na condição de potencializadora de reflexão sobre o papel da intervenção científica no mundo.

\section{Referências}

ARAÚJO, A. F. O monstro de Frankenstein: uma leitura à luz do imaginário educacional. Revista Temas em Educação, João Pessoa, v. 23, n. 1, p. 14-35, 2014. Disponível em: https://periodicos.ufpb. br/index.php/rteo/article/view/18790. Acesso em: 22 set. 2020.

BARBOSA, M. R. Revolução científica e nascimento da ciência experimental em Alexandre Koyré. 2013. 110 f. Dissertação (Mestrado em História) - Universidade Federal de Goiás, Goiânia, 2013. Disponível em: http://repositorio.bc.ufg.br/tede/handle/tde/3031. Acesso em: 22 set. 2020.

COUTINHO, A. Notas de teoria literária. Petrópolis: Vozes, 2008.

ECO, U. Sobre o espelho e outros ensaios. Rio de Janeiro: Nova Fronteira, 1989.

FERNEDA, T. A ciência em romances de ficção científica: leituras e caminhos para a educação em ciências. 2015. 166 f. Dissertação (Mestrado em Educação) - Faculdade de Educação, Universidade Federal de São Carlos, São Carlos, 2015. Disponível em: https://repositorio.ufscar.br/handle/ ufscar/2754. Acesso em: 22 set. 2020.

FIGUEIREDO, G. G. Frankenstein: romantismo, filosofia e ciência no fim do século XVIII e início do século XIX. 2009. 41 f. Trabalho de Conclusão de Curso (Graduação em História) -Universidade Federal do Rio Grande do Sul, Porto Alegre, 2009. 
FOUREZ, G. A construção da ciência: introdução à filosofia e à ética das ciências. São Paulo: Ed. Unesp, 1995.

GOLDFARB, A. M. A. Da alquimia à química. 3. ed. São Paulo: Landy, 2001.

GOMES, A. S. A ciência monstruosa em Frankenstein: aspectos do pós-humano. Gragoatá, Niterói, v. 23, n. 47, p. 848-872, 2018.

GUIMARÃES, A. R. Mary Shelley: vida e obra. In: ARAÚJO, A. F.; ALMEIDA, R.; BECCARI, M. (org.). O mito de Frankenstein: imaginário \& educação. São Paulo: Feusp, 2018. p. 32-70.

GUIMARÃES, A. R.; ARAÚJO, A. F. Como criar um monstro: o manual de instruções do Dr. Victor Frankenstein. In: ARAÚJO, A. F.; ALMEIDA, R.; BECCARI, M. (org.). O mito de Frankenstein: imaginário \& educação. São Paulo: Feusp, 2018. p. 71-87. Disponível em: https://cutt.ly/MfGwe2W. Acesso em: 12 mar. 2019

GUIMARÃES, P. A. "Like an inspired and desperate alchymist": ler/ser Frankenstein no cruzamento das ciências e das humanidades. In: ARAÚJO, A. F.; ALMEIDA, R.; BECCARI, M. (org.). O mito de Frankenstein: imaginário \& educação. São Paulo: Feusp, 2018. p. 175-197.

GUINSBURG. J. O romantismo. 3. ed. São Paulo: Perspectiva, 1993.

HENRY, J. A revolução científica e as origens da ciência moderna. Rio de Janeiro: Jorge Zahar, 1998.

HITCHCOCK, S. T. Frankenstein: as muitas faces de um monstro. São Paulo: Larousse, 2010.

LEVIN, L. Tudo é ficção científica. ComCiência: revista eletrônica de jornalismo científico, Campinas, n. 160, p. 1-5, 2014. Disponível em: https://cutt.ly/3fGwL6E. Acesso em: 24 de jan. 2019.

PAZ, O. Signos em rotação. 3. ed. São Paulo: Perspectiva, 2006.

PEDRO, A. P. Ética, moral, axiologia e valores: confusões e ambiguidades em torno de um conceito comum. Kriterion: revista de filosofia, Belo Horizonte, n. 130, p. 483-49, 2014.

PIASSI, L. P. Contatos: a ficção científica no ensino de ciências em um contexto sociocultural. 2007. 453 f. Tese (Doutorado em Educação) - Universidade de São Paulo, São Paulo, 2007.

ROBERTS, A. Science fiction. London: Routledge, 2000.

SANTOS, B. S. Um discurso sobre ciências. Porto: Afrontamentos, 1988.

SHELLEY, M. Frankenstein: ou o Prometeu moderno. 4. ed. São Paulo: Companhia das Letras, 1994.

SNOW, C. P. As duas culturas e uma segunda leitura. São Paulo: EDUSP, 1995.

ZANETIC, J. Literatura e cultura científica. In: ALMEIDA, M. J. P. ; SILVA, H. C. Linguagens, leituras e ensino da ciência. Campinas: Mercado das Letras, 1998. p. 11-36.

ZANETIC, J. Física e arte: uma ponte entre duas culturas. Pro-Proposições, Campinas, v. 17, n. 1, p. 39 57, 2006. Disponível em: https://cutt.ly/yfGeGzF. Acesso em: 5 jun. 2020. 